\title{
RESENHA: Educação de surdos e educação inclusiva: reflexões sobre a aquisição (ou não) da língua brasileira de sinais
}

\author{
Diléia Aparecida Martins \\ Pontifícia Universidade Católica de Campinas, Campinas-SP, Brasil
}

Souza, R. M., Silvestre, N., \& Arantes, V. A. (Orgs.). (2007). Educação de surdos: Pontos e contrapontos. São Paulo: Summus.

O quarto volume da coleção "Pontos e Contrapontos" da Editora Summus problematiza a educação da pessoa surda. Na apresentação, a organizadora Valéria Amorim Arantes propõe um mapa de leitura para a reflexão sobre a educação de surdos diante das mudanças decorrentes do reconhecimento da língua brasileira de sinais. Nessa perspectiva, o livro apresenta o debate de duas educadoras, Regina Maria de Souza e Núria Silvestre, sobre as concepções que atualmente fundamentam a educação de surdos.

Na primeira parte do livro, a educadora Regina Maria de Souza analisa o pensamento de Skinner, Vigotski, Piaget e Chomsky ao refletir sobre a forma na qual a surdez pode ser estudada a partir da psicanálise. Pela análise do Decreto 5.626 de dezembro de 2005, a autora ressalta aspectos referentes à realidade de sujeitos que se constituem em espaços de fronteira lingüística. Como exemplo, apresenta o caso de María, munícipe de Rivera, fronteira Uruguai-Brasil. De acordo com a autora, María vive uma condição semelhante a de surdos sinalizadores por residir em um lugar fronteiriço, entre dois grupos culturais. Diante de uma ordem socialmente imposta em seu locus de origem (Uruguai), nega o uso da língua portuguesa. Embora seja considerada falante dessa língua, não pode se reconhecer como tal devido ao desprestígio ocasionado pelo estabelecimento de uma língua majoritária.

Em contrapartida, Núria Silvestre discute o processo de reabilitação vivenciado pela pessoa surda ao enfatizar o progresso científico e o uso de próteses auditivas e de implante coclear. Reconhece as implicações biológicas da ausência de audição, ao refletir sobre o sofrimento da família diante do nascimento inesperado de uma criança surda e destaca alguns fatores, tais como: a baixa auto-estima dos pais por gerar um filho considerado incompleto, a busca por orientação, a percepção de possibilidades de integração dessa criança à sociedade. A autora afirma que diferentes profissionais poderiam colaborar no processo de integração, na alfabetização e no contato com a língua oral e escrita.

O contraponto existente entre as duas autoras, proposto na segunda parte do livro, é justamente a forma com que esse sujeito surdo é reconhecido. $\mathrm{O}$ texto provoca certas inquietações: quando nos voltamos para questões educacionais referentes à linguagem, de que ponto de vista se compreende a apropriação e o uso da língua? A pessoa surda deve se apropriar da língua oral ou da língua de sinais? De que vale o foco ostensivo na aquisição da língua oral, ou da língua de sinais, sem refletirmos sobre a realidade da pessoa surda em diferentes condições sociais e culturais? Podemos pensar que a compreensão do sujeito surdo enquanto deficiente, ou não, estaria relacionada a uma ideologia majoritária socialmente imposta?

Entre vertentes aparentemente contrárias, percebemos a preocupação de garantir o pleno desenvolvimento de pessoas que historicamente foram privadas do acesso à escolarização. Assim, a obra proporciona um intenso debate sobre as diferentes concepções referentes à educação da pessoa surda.

$\mathrm{Na}$ terceira parte do livro Valeria Amorim Arantes, Núria Silvestre e Regina Maria de Souza dialogam e refletem sobre a atual realidade 
educacional. Núria Silvestre questiona a incompreensão sobre a existência de diferentes realidades de surdez e de que a todos é garantido o direito de se apropriar da linguagem de forma a corresponder aos seus ideais de classe e de grupo-comunidade. Nesse sentido, leis poderiam ajudar a dirigir a sociedade, mas não impor verdades incontestáveis, portanto, a visão de algumas pessoas acerca da língua de sinais poderia estar equivocada. Regina Maria de Souza afirma que a apropriação da língua ultrapassa a emissão de sons e palavras, compondo uma relação de significação, superando o uso mecânico de próteses auditivas. Considera ainda a importância que a escrita tem para a sociedade enquanto registro da memória e da vivência de valores construídos, também, na oralidade.

Dentre tantos outros, destaquei alguns dos pontos e contrapontos apresentados nessa obra que proporciona a reflexão acerca da Educação de Surdos no atual contexto da educação inclusiva.

Artigo recebido em 21/05/2007.

Aceito para publicação em 04/06/2007.

Endereço para correspondência:

Diléia Aparecida Martins. Rua Riciere Motta, 180. CEP: 13140-000, Paulínia-SP, Brasil. E-mail:

\section{dileiamartins@hotmail.com}

Diléia Aparecida Martins é graduada em Pedagogia com formação em educação especial pela Pontifícia Universidade Católica de Campinas-SP, mestranda do Programa de Pós-graduação em Educação desta instituição. 